\title{
Efektifitas Probiotik Lactobacillus casei dan Lactobacillus rhamnosus Sebagai Pengganti Antibiotic Growth Promoter Terhadap Total Kolesterol, Low Density Lipoprotein dan High Density Lipoprotein Ayam Broiler
}

\author{
Effectivty of Probiotic Lactobacillus casei and Lactobacillus rhamnosus as Alternate \\ Antibiotic Growth Promoter on Cholesterol, Low Density Lipoprotein and High Density \\ Lipoprotein of Broiler Chickens
}

\author{
Anita Dwi Andriani ${ }^{1}$, Widya Paramita Lokapirnasari2*, Balqis Karimah ${ }^{1}$, Sri Hidanah', \\ M. Anam Al-Arif ${ }^{2}$, Soeharsono ${ }^{3}$, Nenny Harijani ${ }^{4}$ \\ ${ }^{1}$ Magister of Veterinary Agribusiness, ${ }^{2}$ Department of Animal Husbandry, ${ }^{3}$ Department of Veterinary Anatomy, \\ ${ }^{4}$ Department of Veterinary Public Health \\ Faculty of Veterinary Medicine, Universitas Airlangga, \\ UNAIR C-Campus Mulyorejo, Surabaya, Jawa Timur, Indonesia, 60115 \\ *Corresponding author: widyaparamitalokapirnasari@gmail.com
}

\begin{abstract}
Abstrak
Penelitian ini bertujuan untuk mengetahui efektifitas probiotik Lactobacillus casei dan Lactobacillus rhamnosus sebagai pengganti Antibiotic Growth Promoter (AGP) terhadap total kolesterol, Low Density Lipoprotein (LDL) dan High Density Lipoprotein (HDL) pada ayam pedaging. Ayam broiler sebanyak 18 ekor day old chick diacak kedalam enam perlakuan (P0, P1, P2, P3, P4 dan P5) setiap perlakuan terdiri dari 3 ulangan, yakni (P0) 100\% pakan basal, (P1) pakan basal+0.01 gram AGP/kg pakan, (P2) pakan basal+probiotik $0.05 \mathrm{gram} / \mathrm{kg}$ pakan, (P3) pakan basal+probiotik 0.1 gram $/ \mathrm{kg}$ pakan, (P4) pakan basal+probiotik 0.025 gram/liter air minum, (P5) pakan basal+probiotik 0.05 gram/liter air minum. Data di analisis menggunakan uji Multivariate Analysis of Variance (MANOVA) dilanjutkan uji Duncan. Hasil menunjukkan bahwa pemberian probiotik berbeda nyata $(\mathrm{p}<0.05)$ dengan pemberian AGP. Pemberian probiotik L. casei dan L. rhamnosus dengan dosis 0.05 gram $/ \mathrm{kg}$ pakan, 0.01 gram $/ \mathrm{kg}$ pakan, 0.025 gram $/$ liter air minum dan $0.05 \mathrm{gram} / \mathrm{liter}$ air minum sebagai pengganti AGP dapat menurunkan total Kolesterol dan LDL serta meningkatkan kadar HDL pada ayam broiler. Dapat disimpulkan bahwa penambahan probiotik pada pakan dan air minum dapat menurunkan total kolesterol dan LDL serta menaikkan kadar HDL pada ayam broiler.
\end{abstract}

Kata kunci: probiotik, antibiotic growth promoter, kolesterol, low density lipoprotein, high density lipoprotein

Abstract

This study aimed to determine effectifity of probiotic Lactobacillus casei and Lactobacillus rhamnosus supplementation to the alternate Antibiotic Growth Promoter (AGP) on cholesterol, total Low Density Lipoprotein $(L D L)$ and High Density Lipoprotein (HDL) of Broiler Chickens. A total of 18 broiler chickens day old chick, were completely randomized into six treatments with each treatment had three replications. The treatments were (P0) standard feed, (P1) standard feed with 0.01 gram AGP/kg feed, (P2) standard feed with $0.05 \mathrm{gram} / \mathrm{kg}$ feed, (P3) standard feed with 0.1 gram $/ \mathrm{kg}$ feed, (P4) standard feed with 0.025 grams probiotic/liter drinking water and (P5) standard feed with 0.05 grams probiotic/liter drinking water. Data analyzed use the Multivariate Analysis of Variance (MANOVA) method then followed by Duncan Test. The results showed that there was a significant difference among the treatments $(p<0.05)$. Probiotic administration of $0.05 \mathrm{gram} / \mathrm{kg}$ feed, $0.1 \mathrm{gram} / \mathrm{kg}$ feed, 0.025 grams probiotic/liter drinking water and 0.05 grams probiotic/liter drinking water can reduce cholesterol and total LDL, but increase HDL. It could be concluded, that probiotic administration can be an alternative AGP specifically reduce cholesterol and LDL, but increase $H D L$.

Key words: probiotics, antibiotic growth promoter, cholesterol, low density lipoprotein, high density lipoprotein 


\section{PENDAHULUAN}

Pola konsumsi pada masyarakat semakin sadar pentingnya kesehatan terutama dari sumber penyedian bahan pangan yang diperoleh dari protein hewani semakin tinggi. Kebutuhan dasar konsumsi akan pangan asal hewani khususnya unggas yang mengandung rendah kolesterol dan lemak semakin banyak dibutuhkan masyarakat. Bahan pangan dengan kolesterol tinggi dapat menjadi penyebab gejala pembesaran hati, pankreatitis dan peningkatan konsentrasi very low density lipoprotein (VLDL) yang kemudian akan meningkatkan risiko arteriosklerosis sebab arteri pembuluh darah menjadi sempit dan alirah darah menjadi terhambat yang dimana akan menimbulkan berbagai penyakit seperti stroke jika aterosklerosis terjadi pada pembuluh darah otak, jantung koroner, dan kematian (Wijaya et al., 2013). Penambahan feed additive dalam ransum ayam diperlukan untuk menjadikan produk pangan utamanya dari sektor ternak yang rendah kolesterol serta sebagai salah satu upaya untuk meningkatkan produksi ternak pada ayam.

$$
\text { Pertimbangan utama konsumen }
$$
mengkonsumsi sumber pangan dari bahan hewani adalah lemak yang cukup tinggi. Sumber kolestrol yang tinggi dapat menyebabkan penyakit degeneratif seperti jantung koroner (Meliandasari et al., 2015). Bahan-bahan pangan yang mengandung kolesterol yang melampaui batas normal atau tinggi akan mengendap pada dinding pembuluh darah sehingga menyebabkan penyumbatan pembuluh darah disebut atherosclerosis (Rusmana et al., 2008). Kolesterol dihasilkan dari produk metabolisme hewan dan terkandung di dalam makanan yang diproduksi oleh hewan seperti daging, otak, kuning telur, dan hati, Kolesterol adalah komponen lemak yang diperlukan dalam tubuh dan memiliki peran dalam terbentuknya testis, hormon, ovarium dan anak ginjal (Sumardi et al., 2016). Vitamin A,D,E,K dapat terlarut dengan adanya peran kolesterol. Kolestrol menjadi unsur pokok penyusun membran sel. Kandungan kolesterol yang terlalu tinggi berpengaruh utama terjadinya pengerasan dan pengapuran dinding pembuluh darah yang mengakibatkan gangguan saluran pembuluh darah koroner serta mengakibatkan stroke yaitu keadaan pecahnya pembuluh darah otak (Dalimartha, 2002).

Sumber protein hewani mudah diperoleh dari ayam broiler dan sangat menjanjikan untuk diternakkan. Daging dengan kadar kolesterol dan lemak yang rendah tetapi mengandung asam lemak esensial tinggi menjadi preferensi konsumen menengah keatas meskipun harus membayar dengan harga yang lebih mahal.

Kadar kolestrol pada daging ayam broiler dipengaruhi kadar protein pada ransum, semakin tinggi protein ransum maka semakin tinggi kadar kolesterol pada daging ayam broiler yang di hasilkan (Sujana et al., 2007). Guna mendapatkan hasil daging dengan kualitas premium dengan kadar kolesterol dan Low Density Lipoprotein (LDL) rendah dan High Density Lipoprotein (HDL) yang tinggi, diperlukan suatu usaha untuk menjadikan produk pangan hewani yang rendah kolesterol.

Penggunaan antibiotik sebagai bahan tambahan dalam pakan bertujuan untuk meningkatkan ketersedian lemak dan protein bagi ayam pedaging. Senyawa antibiotik digunakan sebagai growth promoter dimana dapat meningkatkan efesiensi pakan (feed efficiency) dan reproduksi pada ternak meskipun dalam jumlah yang relatif kecil. Pemberian antibiotik yang berkelanjutan dan tidak sesuai takaran dapat menimbulkan permasalahan baru, yaitu meningkatkan bakteri yang resisten terhadap antibiotik. Penggunaan antibiotik di beberapa negara telah dibatasi penggunaannya, hal ini disebabkan karena dapat memicu mikroorganisme yang ada dalam tubuh manusia maupun ternak (terutama bakteri-bakteri patogen seperti Salmonella, E. coli dan Clostridium perfringens) menjadi resisten terhadap antibiotik tertentu. Residu antibiotik dalam produk yang dihasilkan yang dapat menjadi racun bagi konsumen (Král et.al., 2012). Oleh kejadian resistensi antibiotik, perlu alternative pengganti antibiotik, yaitu dengan menggunakan probiotik. Probiotik adalah pakan tambahan yang mekanisme kerjanya mempertahankan keseimbangan pada saluran pencernaan dengan 
cara mempengaruhi mikroflora usus dan mengeliminasi mikroorganisme patogen dalam usus. Peran probiotik yaitu dapat menimbulkan lingkungan yang tidak nyaman untuk pertumbuhan bakteri patogen yaitu dengan menghasilkan suasana asam pada saluran pencernaan (Astini, 2014). Bakteri sebagian dapat dijadikan sebagai probiotik, salah satu bakteri yang berperan sebagai probiotik adalah bakteri asam laktat (BAL) (Trisna. et al., 2012). Bakteri Asam Laktat (BAL) merupakan kelompok bakteri yang telah banyak digunakan sebagai probiotik (Margino et al., 2017). Bakteri asam laktat memproduksi asam organik yang mampu digunakan untuk mencegah koloni bakteri patogen dalam usus halus, menghasilkan bakteriosid untuk menghambat pertumbuhan bakteri patogen (Abun, 2008). Jenis bakteri asam laktat diantaranya adalah Bacillus sp. Lactobacillus sp. dan Saccharomyces cerevisiae.

Bakteri Lactobacillus casei digolongkan ke dalam probiotik karena dapat meningkatkan kesehatan unggas. Bakteri ini dapat meningkatkan fungsi pencernaan dengan cara memproduksi asam laktat yang dapat menurunkan jumlah bakteri merugikan dalam saluran pencernaan (Cahyanti, 2011). Berkurangnya bakteri merugikan di dalam saluran pencernaan menghasilkan penyerapan nutrisi yang lebih baik oleh saluran cerna. Lactobacillus rhamnosus pada dosis tertentu juga dapat mengatur respon kekebalan tubuh pada saluran pencernaan (Gao et al., 2015). Hal ini akan menjadikan saluran cerna lebih sehat dan lebih maksimal dalam penyerapan nutrisi pakan, sehingga akan berdampak pada performa unggas yang lebih baik.

Penelitian bertujuan untuk mengetahui penambahan probiotik sebagai pengganti Antibiotic Growth Promoter (AGP) terhadap total kolesterol, kadar LDL dan HDL ayam broiler.

\section{METODE PENELITIAN}

\section{Lokasi dan Waktu Penelitian}

Penelitian dilaksanakan di kandang hewan coba Fakultas Kedokteran Hewan Universitas
Airlangga selama 5 minggu. Selanjutnya untuk pengambilan darah ayam dilakukan di ex Laboratorium Patologi dan untuk pemeriksaan darah ayam broiler dilakukan di Laboratorium Farmasi Fakultas Kedokteran Universitas Muhammadiah Malang.

\section{Alat dan Bahan}

Hewan coba yang digunakan dalam penelitian ini adalah ayam broiler DOC strain Cobb yang diproduksi PT. Wonokoyo Jaya Corporindo, pakan komersial yang digunakan untuk ayam pedaging pakan starter berupa pakan komersil BR511. Desinfektan menggunakan benzalkonium chloride 10\%, dan air minum menggunakan air bebas chlorine. Bahan-bahan yang digunakan dalam penelitian ini adalah Probiotik yang mengandung bakteri asam laktat L. casei dan L. rhamnosus dengan konsentrasi $1.2 \times 10^{8} \mathrm{CFU} / \mathrm{gram}$. AGP Virginamycin.

\section{Perlakuan}

Sebanyak 18 ekor diacak kedalam enam perlakuan (P0, P1, P2, P3, P4 dan P5) setiap perlakuan terdiri dari 3 ulangan, yang terdiri dari (P0) $100 \%$ pakan basal, (P1) pakan basal+0.01 gram AGP/kg pakan, (P2) pakan basal+probiotik $0.05 \mathrm{gram} / \mathrm{kg}$ pakan, (P3) pakan basal+probiotik 0.1 gram $/ \mathrm{kg}$ pakan, (P4) pakan basal+probiotik 0.025 gram/liter air minum, (P5) pakan basal+probiotik 0.05 gram/liter air minum. Cara pemberian AGP melalui pakan yaitu, sebanyak 0.01 gram AGP dicampur dan diaduk rata dalam $1 \mathrm{~kg}$ pakan. Cara pemberian probiotik air minum yaitu, sebanyak 0.05 gram (P2) probiotik dilarutkan dalam $9.95 \mathrm{ml}$ air (bebas chlorine dan desinfektan lainnya), 0.1 gram (P3) probiotik dilarutkan dalam $9.9 \mathrm{ml}$ air, diaduk hingga merata, lalu didiamkan selama 24 jam tanpa aerasi agar berkembang lebih banyak. Total 1 liter larutan probiotik tersebut kemudian di semprotkan ke pakan ayam pedaging, kemudian pakan siap di berikan untuk ternak. 0.025 gram/liter probiotik (P4) dilarutkan dalam $999.975 \mathrm{ml}$ air dan 0.05 gram/liter probiotik (P5) dilarutkan dalam $999.96 \mathrm{ml}$ air, diaduk hingga merata, lalu didiamkan selama 24 jam tanpa aerasi agar berkembang lebih banyak. Larutan 
probiotik dicampurkan ke dalam air minum ayam pedaging, minum siap diberikan. Pembuatan larutan probiotik dilakukan setiap hari dan pencampuran air minum dilakukan setiap akan memberikan air minum.

\section{Pengambilan Serum Darah Ayam}

Ayam dipegang dengan hati-hati, kemudian swab daerah sayap menggunakan kapas beralkohol sehingga vena brachialis terlihat dengan jelas, setelah terlihat dilanjutkan dengan proses pengambilan darah menggunakan spuit 3 $\mathrm{ml}$ dengan jarum $23 \mathrm{G}$ tepat dibawah tendon pronator muskulus kemudian arahkan jarum tepat ke vena brachialis. Darah diambil secara perlahan sebanyak $\pm 1 \mathrm{ml}$ kemudian dimassukkan ke dalam tabung mikrotube $3 \mathrm{ml}$ lalu diberi label penamaan setiap perlakuan dan ulangan, darah didiamkan selama 15 menit, kemudian serum di ambil dan di masukkan ke dalam tabung eppendorf untuk kemudian dilakuan sentrifuge pada kecepatan $3000 \mathrm{rpm}$ selama 10 menit. Serum di simpan pada cooler box suhu $4^{\circ} \mathrm{C}$. Uji Darah ayam broiler dilakukan di Laboratorium Farmasi Fakultas Kedokteran Universitas Muhammadiah Malang.

\section{Analisis Data}

Hasil pemeriksaan darah ayam broiler yang didapat dianalisis statistik menggunakan Multivariate Analysis of Variance (MANOVA) untuk mengetahui apakah terdapat perbedaan yang nyata dari perlakuan yang diberikan. Apabila diperoleh hasil yang berbeda atau berbeda sangat nyata maka dilanjutkan dengan Uji Jarak Berganda Duncan (Kusriningrum, 2008). Analisis statistik menggunakan program SPSS for Windows 21.0 (IB, USA).

\section{HASIL DAN PEMBAHASAN}

Hasil analisis MANOVA menunjukkan bahwa penambahan probiotik $L$. casei dan $L$. rhamnosus sebagai pengganti AGP menunjukkan total kolesterol, LDL dan HDL terdapat perbedaan yang nyata $(p<0,05)$. Kemudian dilanjutkan dengan Uji Jarak Berganda Duncan karena hasil menunjukkan berbeda nyata dan pada hasil total kolesterol pemberian probiotik pada perlakuan $\mathrm{P} 2, \mathrm{P} 3, \mathrm{P} 4$ dan P5 berbeda nyata dengan P1. Hasil LDL menunjukkan perlakuan dengan pemberian probiotik berbeda nyata dengan pemberian AGP (P1) dan pada hasil HDL pada perlakuan pemberian probiotik melalui pakan dan air minum menunjukkan perbedaan yang nyata dengan perlakuan pemberian AGP. Hasil total kolesterol, LDL dan HDL dapat dilihat pada Tabel 1 dan grafik total kolesterol, LDL dan HDL dapat dilihat pada Gambar 1.

Pada penelitian menunjukkan bahwa pemberian probiotik dapat menurunkan total kolesterol, LDL dan meningkatkan kadar HDL pada ayam broiler. Hasil menunjukkan pemberian probiotik dengan konsentrasi $10^{8}$ CFU/g melalui pakan dan air minum dapat memberikan perubahan pada rasio LDL dan HDL sehingga dapat merubah kadar kolesterol dari pada pemberian AGP. Pemberian probiotik Lactobacillus sp. Sudah optimal dalam meningkatkan penyerapan nutrisi dan memproduksi enzim bile salt hydrolise (BSH). Enzim BSH dapat menurunkan kadar kolesterol darah, enzim lipase, dan trigliserida darah tanpa meninggalkan residu yang mudah diserap oleh usus karena mempunyai kemampuan dalam memutuskan asam lemak rantai panjang menjadi asam lemak rantai sedang dan rantai pendek (Saputri dkk., 2012).

Plasma darah mengandung kolesterol sebanyak $80 \%$ yang berasal dari kolesterol yang disintesis oleh hati. Sintesis pada hati dan empedu dipengaruhi oleh seberapa banyak suplai kolesterol yang tersedia di dalam pakan. Tinggi dan rendahnya kolesterol dalam tubuh dipengaruhi oleh kecepatan sintesis kolesterol didalam tubuh yang dipengaruhi oleh kemampuan sintesis hati dan empedu. (Wijaya $e t$ al., 2013). Respon yang berhubungan dengan perubahan derajat asam lemak bebas pada pakan adalah perubahan pada tingkat kolesterol di dalam darah, karena asam lemak bebas akan diubah menjadi asil koA. Asetil ko-A merupakan prekusor utama pembentukan kolesterol (Lovita, 2005). Bakteri probiotik juga mempunyai kemampuan merubah asam lemak bebas menjadi 
Tabel 1. Rata-rata dan simpangan baku total kolesterol, LDL dan HDL serum ayam broiler

\begin{tabular}{cccc}
\hline \multirow{2}{*}{ Perlakuan } & \multicolumn{3}{c}{ Rata-rata \pm SD } \\
\cline { 2 - 4 } & Total Kolesterol $(\mathbf{m g} / \mathbf{d l})$ & LDL $(\mathbf{m g} / \mathbf{d l})$ & HDL $(\mathbf{m g} / \mathbf{d l})$ \\
\hline P0 & $182.3^{\mathrm{a}} \pm 6.39$ & $108.6^{\mathrm{a}} \pm 5.16$ & $34.5^{\mathrm{c}} \pm 13.41$ \\
P1 & $131.1^{\mathrm{b}} \pm 1.46$ & $61.5^{\mathrm{b}} \pm 7.36$ & $47.4^{\mathrm{bc} \pm 9.48}$ \\
P2 & $121.4^{\mathrm{b}} \pm 6.33$ & $51.2^{\mathrm{c}} \pm 5.17$ & $51.7^{\mathrm{ab}} \pm 6.09$ \\
P3 & $116.7^{\mathrm{c}} \pm 4.97$ & $42.2^{\mathrm{d}} \pm 3.27$ & $59.2^{\mathrm{ab}} \pm 2.12$ \\
P4 & $112.6^{\mathrm{c}} \pm 9.06$ & $34.1^{\mathrm{d}} \pm 3.05$ & $64.8^{\mathrm{a}} \pm 5.12$ \\
P5 & $121.6^{\mathrm{bc}} \pm 2.11$ & $54.1^{\mathrm{bc}} \pm 3.43$ & $48.1^{\mathrm{bc}} \pm 3.30$ \\
\hline
\end{tabular}

a,b,c superskrip berbeda pada kolom yang sama menunjukkan perbedaan nyata $(\mathrm{p}<0.05)$

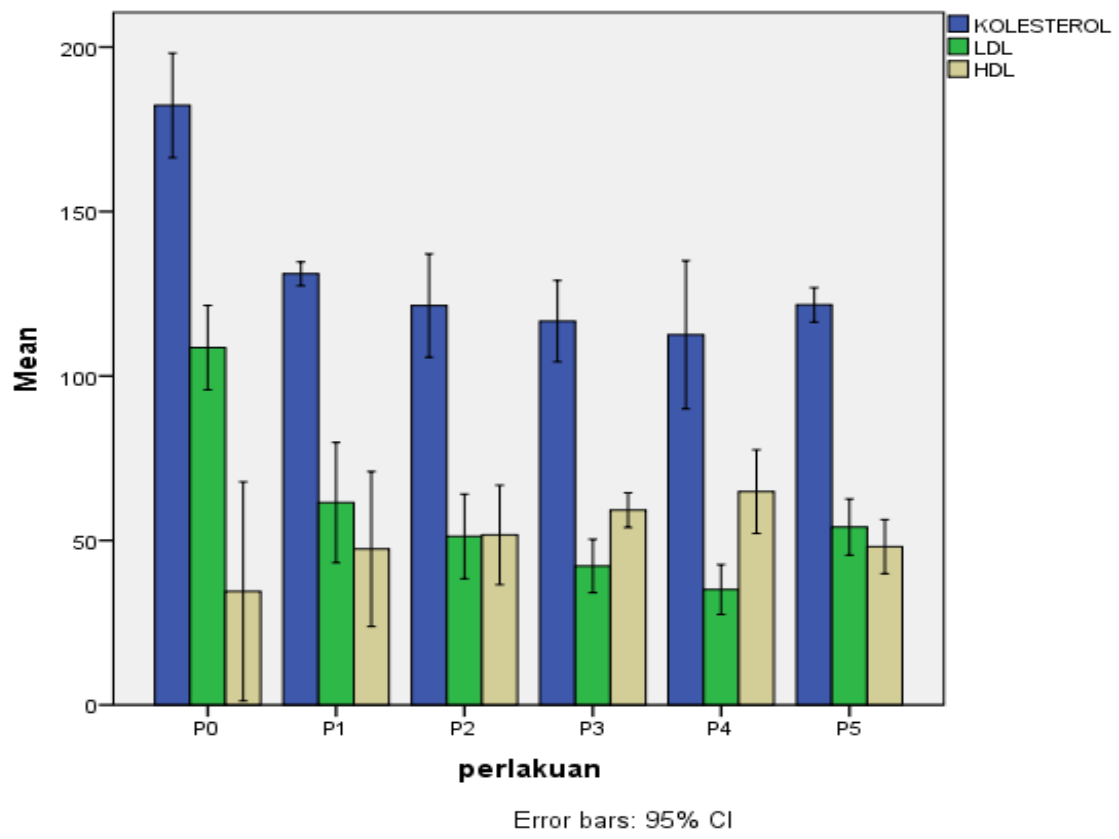

Gambar 1. Grafik rata-rata total kolesterol, LDL dan HDL

bentuk ester yang berbeda dari trigliserida pada saluran pencernaan dalam mensintesis enzim esterase yang bersamaan dengan enzim lipase (Mahdavi et al., 2005).

Kualitas daging ayam ditentukan oleh faktor sebelum dan sesudah pemotongan. Bahan tambahan pakan (aditif) merupakan salah satu faktor sebelum pemotongan yang dapat memengaruhi kualitas daging ayam (Soeparno, 2009). Aplikasi probiotik pada ayam broiler diterapkan dengan tujuan antara lain menggantikan antibiotik. Cara kerja antibiotik dalam meningkatkan produktifitas ayam dengan cara membunuh bakteri patogen di dalam usus sehingga bakteri bermanfaat yang ada di dalam usus dapat berkembang dengan baik. Probiotik bekerja dengan meningkatkan jumlah bakteri non patogen di dalam usus. Bakteri non pathogen dapat mengubah suasana saluran usus terutama potensial hidrogen $(\mathrm{pH})$ menjadi asam sehingga menaikkan kekebalan saluran cerna. Probiotik bekerja dengan cara menghasilkan bakteriosid dan asam organik rantai pendek (laktat, asetat, propionat). Zat-zat tersebut dapat menghambat proses pertumbuhan mikroba yang merugikan sehingga mikroba yang menguntungkan dan bermanfaat bisa bersaing untuk mendapatkan tempat di epitel usus. Probiotik dan mikroba baik endogen tersebut dengan kemampuan adhesinya pada mukosa usus dapat menjadi penghalang terhadap patogen sehingga meningkatkan imunitas dan meningkatkan penyerapan nutrien (Alloui et al., 2013).

Kadar kolesterol darah pada semua perlakuan masih dalam kisaran normal yaitu antara $112.6-182.3 \mathrm{mg} / \mathrm{dl}$, dimana hasil tersebut sesuai dengan pernyataan Mangisah (2003) yang 
menjelaskan bahwa kadar kolesterol darah ayam normal berkisar antara 125-200 mg/dl. Kadar kolesterol yang rendah terdapat pada perlakuan $\mathrm{P} 4$ yaitu penambahan probiotik 0.025 gram/liter melalui air minum yaitu $112.6 \mathrm{mg} / \mathrm{dl}$ dan dengan penambahan probiotik 0.1 gram $/ \mathrm{kg}$ pakan (P3) yaitu $116.7 \mathrm{mg} / \mathrm{dl}$. Faktor penyebab turunnya kadar kolesterol darah adalah dengan dekonjugasi garam empedu karena adanya aktivitas BSH yang dimiliki oleh bakteri Lactobacillus sp. Sel probiotik mempunyai kemampuan dalam mendekonjugasi garam empedu yang berhubungan dengan kolesterol yang ada dalam darah dan saluran pencernaan. Garam empedu akan didekonjugasi menjadi asam empedu bebas yang bersifat tidak dapat diserap dan disekresi bersama feses jika sel probiotik mempunyai aktivitas BSH. Tingginya aktivitas BSH dalam mendekonjugasi asam empedu, semakin banyak asam empedu yang akan dikeluarkan. Tubuh akan mengambil kolesterol dalam darah untuk digunakan sebagai prekursor sintesa garam empedu yang baru, sehingga kadar kolesterol dalam darah akan turun (Astuti et al., 2009). Berdasarkan penelitian (Ashayerizadeh et al., 2011) menunjukkan penggunaan probiotik dengan kandungan $L$. casei dapat meningkatkan efisiensi energi dan protein serta dapat menurunkan kandungan kolesterol darah.

Rata-rata pada hasil penelitian menunjukkan kadar HDL adalah 34.5-64.8 mg/dl. Hasil analisis statistik menunjukkan pemberian probiotik memberikan perbedaan yang nyata $(p<0.05)$ terhadap kadar HDL. Kadar HDL darah ayam broiler normal menurut Miruka dalam Manoppo et al (2017) adalah 40-60mg/dl yang dimana rendah kalau $<40$ dan tinggi kalau $>60$. Hasil rerata HDL pada pemberian probiotik 0.025 gram/liter melalui air minum menunjukkan kadar HDL tertinggi yaitu 64.8 $\mathrm{mg} / \mathrm{dl}$, dimana hasil tersebut diatas normal. Kadar HDL yang meningkat menunjukkan terdapat respons dari perlakuan yang diberikan. Menurut Hartini (2009), kadar HDL yang tinggi mencegah tejadinya risiko aterosklerosis dengan cara mengangkut kolesterol dari jaringan perifer menuju hepar dan mengurangi kolesterol yang berlebihan. Menurut Murray et al. (2012), HDL merupakan lipoprotein yang mengangkut lipid dari perifer menuju ke hepar. Molekul HDL dapat melewati sel endotel vaskular dan masuk ke dalam intima untuk mengangkut kembali kolesterol yang terkumpul dalam makrofag karena molekul HDL mempunyai ukuran yang relatif kecil dibandingkan lipoprotein lain. HDL juga dapat mencegah oksidasi LDL yang terdapat dalam salah satu sifat dari HDL yang mempunyai sifat anti-oksidan. Kadar HDL yaitu dipengaruhi oleh genetik dan lingkungan, antara lain pakan yang diberikan (Hartini, 2009).

Hasil penelitian menunjukkan rerata kadar LDL adalah 34.1-108.6 mg/dl. Pemberian probiotik menunjukkan perbedaan yang nyata ( $\mathrm{p}<0.05)$ terhadap kadar LDL darah ayam broiler. Hal ini menunjukkan pemberian probiotik $L$. casei dan L. rhamnosus berpengaruh terhadap LDL darah ayam broiler. Pada penelitian ini LDL masih dalam kisaran normal. Nilai tersebut terbilang normal bila dibandingkan dengan pendapat Miruka dalam (Manoppo et al., 2007) bahwa kadar LDL ayam yang normal sebesar 95-125 mg/dl. Probiotik yang diberikan dapat dimanfaatkan secara optimal dengan mengeluarkan enzim lipoprotein lipase yang mengatalis gliserol dan asam lemak hingga LDL mengalami perombakan. Pemberian probiotik dapat berpengaruh terhadap penurunan kadar kolesterol jahat (LDL) dan meningkatkan kadar kolesterol baik (HDL) (Sumardi et al., 2016). Kadar LDL terendah terdapat pada perlakuan P4 yaitu pemberian probiotik 0.025 gram/liter melalui air minum dengan kadar LDL 34.1 $\mathrm{mg} / \mathrm{dl}$ dan pada perlakuan dengan pemberian probiotik 0.1 gram $/ \mathrm{kg}$ pakan dengan kadar LDL $42.2 \mathrm{mg} / \mathrm{dl}$. Perlakuan dengan pemberian probiotik berpengaruh terhadap kadar LDL darah ayam karena sintesis LDL banyak dipengaruhi oleh faktor pakan, genetik ayam dan lingkungan (Yusniar, 2009).

\section{KESIMPULAN}

Pemberian probiotik $L$. casei dan $L$. rhamnosus dosis 0.05 gram $/ \mathrm{kg}$ pakan, 0.01 gram $/ \mathrm{kg}$ pakan, 0.025 gram/liter air minum dan 
0.05 gram/liter air minum sebagai pengganti AGP dapat menurunkan total Kolesterol dan LDL serta meningkatkan kadar HDL ayam broiler.

\section{UCAPAN TERIMA KASIH}

Penulis mengucapkan terima kasih kepada Dekan Fakultas Kedokteran Hewan Universitas Airlangga. Terima kasih kepada dosen pembimbing yang selama ini telah memberikan masukan sehingga dapat terselesainya jurnal ini, dan kepada para teman teman penelitian yang telah saling membantu selama proses penelitian.

\section{DAFTAR PUSTAKA}

Abdurrahman, Z.H., Yanti, Y. 2018. Gambaran Umum Pengaruh Probiotik Dan Prebiotik Pada Kualitas Daging Ayam. J. Ternak Trop., 19(2), 95-104.

Abun. 2008. Hubungan Mikroflora dengan Metabolisme dalam Saluran Pencernaan Unggas dan Monogastrik. Makalah ilmiah. Jurusan Nutrisi dan Makanan Ternak. Jatinangor : Fakultas Peternakan, Universitas Padjajaran.

Alloui, M.N., Szczurek, W., Świątkiewicz, S. 2013. The usefulness of prebiotics and probiotics in modern poultry nutrition: a review / przydatność prebiotyków i probiotyków w nowoczesnym żywieniu drobiu - przegląad. Annal. Anim. Sci., 13(1), $17-32$.

Ashayerizadeh, A., Nabiri, N., Mirzadeh, K.H., Ghorbani, M.R. 2011. Effects of dietary supplementation of probiotic on growth indices and serum biochemical parameters of broiler chickens. J. Cell Anim. Bio., 5(8), 152-156.

Astini, W. 2014. Potensi Probiotik Komersial terhadap Pertambahan Berat Badan, Konsumsi Pakan dan Nilai Konversi Pakan
Ayam Broiler. Skripsi. Universitas Airlangga. Surabaya.

Astuti, Bachruddin, Z., Supadmo, Harmayani, E. 2009. Penngaruh Pemberian Bakteri Asam Laktat Streptococcus thermophilus Terhadap Kadar Kolesterol Darah Ayam Broiler Strain Lohman". Yogyakarta: Fakultas MIPA UGM.

Cahyanti, A.N. 2011. Viabilitas Probiotik Lactobacillus casei pada Yoghurt Susu Kambing Selama Penyimpanan Beku. J. Tek. Pertanian, 12(3), 176-180.

Dalimartha S. 2002. Resep Tumbuhan Obat untuk Menurunkan Kolesterol. Cetakan 6. Jakarta (ID): Penebar Swadaya.

Dankowiakowska, A., Kozlowska, I., Bednarczyk, M. 2013. Probiotics, prebiotics and snybiotics in poultry mode of action, limitation, and achievements. J. Centr. Eur. Agric., 14(1), 467-478.

Gao, K., Wong, C., Liu, L., Dou, X., Yuan, L., Zhang, W., Wong, H. 2015. Immunomodulation and Signaling Mechanism of Lactobacillus rhamnosus GG and Its Components on Porcine Intestinal Epithelial Cells Stimulated by Lipopolysaccharide. J. Microbiol. Immunol. Infec., 20, 1-14.

Hartini, M., Okid, P.A. 2009. Kadar kolesterol darah tikus putih (Rattus norvegicus) hiperkolesterolemik setelah perlakun VCO. Bioteknol., 6(2), 55-62.

Kusriningrum, R.S. 2008. Perancangan Percobaan. Airlangga University Press. Surabaya.

Král, M., Angelovicova, M., Mrazova, L. 2012. Application of Probiotics in Poultry Production. Slovak University of Agriculture in Nitra, Faculty of Biotechnology and Food 
Sciences, Department of Food Hygiene and Safety, 949 76-Nitra.

Kvan, O.V., Gavrish, I.A., Lebedev, S.V., Korotkova, A.M., Miroshnikova, E.P., Serdaeva, V.A., Davydova, N.O. 2018. Effect of probiotics on the basis of Bacillus subtilis and Bifidobacterium longum on the biochemical parameters of the animal organism. Environ. Sci. Pollut. Res., 25(3), 2175-2183.

Lovita, A. 2005. Efek Probiotik sebagai Starter dan Implikasi Efeknya terhadap Kualitas Yoguhrt, Ekosistem Saluran, Pencernaan, dan Biokimia Darah Mencit. Disertasi. Fakultas Pascasarjana. Institut Pertanian Bogor. Bogor.

Mahdavi, A.H., Rahmani, H.R., Pourreza, J. 2005. Effect of probiotic supplements on egg quality and laying hen's performance. Int. J. Poult. Sci., 4(7), 488-492.

Manoppo, M.R.A., Sugihartuti, R., Adikara, T.S., Dhamayanti, Y. 2007. Pengaruh Pemberian Crude Chrorella terhadap Total Kolesterol Darah Ayam Broiler. Fakultas Kedokteran Hewan. Universitas Airlangga.

Mangisah, I. 2003. Pemanfaatan Kunyit dan Temulawak Sebagai Upaya Menurunkan Kadar Kolesterol Broiler. Fakultas Peternakan Universitas Diponegoro. Semarang.

Margiono, S., Triyanto, T., Setiawan, F., Setyati, W.A., Pramesti, R. 2017. Aktivitas Antibakteri Isolat Bakteri Asam Laktat Intestinal Udang Panaeid Tipe Liar terhadap Bakteri Vibrio. J. Kelautan Trop., 20(1), 715.

Meliandasari, D., Dwiloka, B., Suprijatna, E. 2015. Daun kayambang (Salvinia molesta) untuk penurunan kolesterol daging dan peningkatan kualitas asam lemak esensial. JATP., 4(1), 22-27.
Murray, R.K., Bender, D.A., Bothan, K.M., Kennelly, P.J., Weil, P.A., Rodwell, V.W. 2012. Harper's Illustrated Biochemistry. The Mc Graw-Hill Companies. Inc. USA.

Rusmana, D., Natawiharja, D., Happali. 2008. Pengaruh pemberian ransum mengandung minyak ikan lemuru dan vitamin $\mathrm{E}$ terhadap kadar lemak dan kolesterol daging ayam broiler. JIT., 8(1), 19-24.

Saputri F. 2012. Pengaruh Pemberian Probiotik Bakteri Asam Laktat (Bal) Pediococcus Pentosaceus Terhadap Keseimbangan Mikroflora Usus Dan 49 Trigliserida Daging Itik Pitalah. Laporan Penelitian Program Pascasarjana Universitas Andalas Padang.

Soeparno. 2009. Ilmu dan Teknologi Daging. Yogyakarta: Gadjah Mada University Press.

Sujana, E., Darana, S., Garnida, D., Wijastutin, T. 2007. Epek Pemberian Ransum Mengandung Tepung Buah Mengkudu Terhadap Kandungan Kolesterol, Persentase Karkas dan Lemak abdomen Ayam Broiler. Seminar Nasional Teknologi peternakan dan Veteriner, Fakultas Peternakan Universitas Padjadjaran Bandung.

Sumardi, Sutyarso, Susanto, G.N., Kurtini, T., Hartono, M., Puspaningsih, N.W. 2016. Pengaruh Probiotik Terhadap Kolesterol Darah Pada Ayam Petelur (layer). J. Ked. Hewan, 10(2).

Trisna, W.N. 2012. Identifikasi Molekuler dan Pengaruh Pemberian Probiotik Bakteri Asam Laktat (Bal) Asal Dadih dari Kabupaten Sijunjung Terhadap Kadar Kolesterol Daging Pada Itik Pitalah Sumber Daya Genetik Sumatera Barat. Artikel. Program Pascasarjana Universitas Andalas, Padang. Hal. 32. 
Wijaya, V., Graha, Ismoyowati, Saleh, D.M. Yusniar, L., Nilasari, E. 2009. Biar Daging 2013. Kajian kadar kolesterol dan trigliserida Ayam Tidak Berkolesterol Tinggi. darah berbagai jenis itik lokal yang pakannya disuplementasi dengan probiotik. JIP., 1(2), 661-668. http://www.majalahtrust.com/biar.daging.ay am.tidak.berkolesterol.tinggi/284.php. 